\title{
Property Wars in Cyprus: The Turkish Position according to International Law
}

- by Murat Metin Hakkı*

\section{Introduction}

11The Cyprus dispute" is a phrase that has been widely used in

1 international affairs since the 1950s. In the beginning it was identified as a conflict between the people of Cyprus, an island in the eastern Mediterranean Sea, and Great Britain - the colonial ruler. At the core appeared to be a demand for self determination by Greeks that constituted the majority of the population. They wanted to exercise this right through Enosis (union) with the Hellenic motherland. The Turkish Cypriot minority population bitterly resisted Enosis. Britain gradually shifted the "Cyprus Dispute" from a colonial dispute to an ethnic conflict between the Turkish and Greek inhabitants of the island although Britain had, in 1914, denounced the 1878 agreement between itself and Turkey over Cyprus by annexing the island. ${ }^{1}$

Since the proclamation of a republic in 1960, the problem has involved Turkey, Greece, the United Kingdom (UK), the United States (US), the United Nations (UN) and recently the European Union (EU). For most of the time that has passed since the resumption of bi-communal troubles in 1963, the issue occupied the top priority in Turkey's foreign policy agenda. It also had a huge impact on Turkish domestic

LL. B. (Southampton), LL. M. (London School of Economics), LL. M. (Cornell), A.M. (Harvard), PgDip. L.P. (London) Member of the New York State Bar, Member of the Cyprus Bar Association, Barrister-at-Law, of the Honourable Society of Gray's Inn. The author can be reached at murathakki@yahoo.com.

1 Murat Metin HAKKI, “The Cyprus Issue: A Documentary History, 1878-2007', (I.B. Tauris: London 2007). 
policy in the 1960s and the 1970s. His failed attempt to intervene militarily in Cyprus in the summer of 1964 de-stabilized Ismet Inonu's government in Turkey that was not able to survive beyond February 1965. After the 1974 military intervention (the "intervention") when Turkey intervened in Cyprus to protect the Turkish Cypriot minority as a reaction to the overthrow of President Makarios by the junta in Athens, Turkey entered a period of international isolation. It took a coup d'état in 1980 to halt the economic and political turmoil that thereby ensued.

In the last 35 years that followed, the UN buffer zone which cuts across Cyprus has created a physical and social barrier between the Greek and Turkish Cypriot communities. It also separates the internationally-recognized administration in the South from the Northern part that is under Turkey's military protection. The Turkish Cypriot community formally declared its independence in 1983 through the Turkish Republic of Northern Cyprus (TRNC), but this move was immediately condemned by UN Security Council Resolutions as null and void. Currently the Turkish Cypriot state is recognized only by Turkey.

It is estimated that $40 \%$ of the Greek population of Cyprus, as well as over half of the Turkish Cypriot population, was displaced following the intervention in the summer of 1974. The figures for internallydisplaced Cypriots vary. The United Nations Peacekeeping force in Cyprus (UNFICYP) estimates 165,000 Greek Cypriots and 45,000 Turkish Cypriots are displaced. The United Nations High Commissioner for Refugees (UNHCR) registers slightly higher figures of 200,000 and 65,000 respectively, being partly based on official Cypriot statistics which register children of displaced families as refugees. ${ }^{2}$

Before the Turkish military intervention, more than $70 \%$ of the island's infrastructure, industry and overall wealth was located in the areas that later came under Turkish control. The year 1974 was a political and financial disaster for the Greek Cypriots. However, for the other major ethnic group the reverse was true. On August 2, 1975, in Vienna, the two parties reached the Voluntary Exchange of Population Agreement, implemented under UN auspices. In accordance with this arrangement, Turkish Cypriots remaining in the South moved to the North and Greek Cypriots remaining in the North moved to the South, with the exception of a few hundred who preferred to reside in the North. After that, the separation of the two communities via the UN-patrolled Green Line prohibited the return of all internally-displaced people.

Between $1955^{3}$ and 1974, the main actors in the "Cyprus Dispute"

\footnotetext{
"Cyprus - Refugees and Social Reconstruction" Countrystudies.us, available at http://countrystudies.us/cyprus/32.htm. 31 April 1955 is the date when the first wave of enduring violence erupted in Cyprus as E.O.K.A. (National Organization of Cypriot Fighters) began its terror spree against the British authorities.
} 


\section{Property Wars in Cyprus: The Turkish Position}

resorted to weapons in order to pursue interests or to defend their rights. Way into the second half of the 1990s, the international community feared that a war could resume between the two communities that would ultimately engulf both sides of the Aegean, i.e. Greece and Turkey. However, from the 1990s onwards, the 'battle of weapons' has been eclipsed by a 'battle of books.' Losing faith in military means to force Turkey's troops out of Cyprus, the Greek side began placing more emphasis on international law in order to emphasize to Turkey's elite the economic and political costs of maintaining the status quo. As will be demonstrated below, the property issue may turn out to be the Achilles heel for the Turkish side.

Loizidou v. Turkey was a landmark legal case regarding the rights of Mrs. Titina Loizidou in wishing to return to her former home in Kyrenia. The Court (ECHR) ruled that she, and persons like her, have the right to return to their former properties and that, despite all the laws passed in the TRNC, they continue to retain title to their former lands. The ECHR ruled that Turkey was responsible for the violation of Mrs. Loizidou's human rights, that she should be allowed to return to her home and that Turkey should pay substantial damages to her, inter alia, for the loss of enjoyment of her home. ${ }^{4}$ After several years of protests, Turkey agreed to pay more than one million US dollars to Mrs. Loizidou, just for the 'loss of use' of her house. ${ }^{5}$

The case has served as a precedent for dozens of cases that have been concluded in a similar fashion. ${ }^{6}$ That the Turkish Cypriots were in general not as economically aggrieved as the Greeks after 1974 may explain the reason why most of the applications emanating from Cyprus have been directed against Turkey. Starting from 2004, the Greek side opened another front at the European Court of Justice (ECJ) through the case Meletis Apostolides v. David Charles Orams and Linda Elizabeth Orams. ${ }^{7}$

Compensating thousands of Greek Cypriot refugees may ultimately make Turkey foot a bill running up to tens of billions of US dollars. Uncertainty as to the ownership of claimed Greek Cypriot-owned land in North Cyprus has had a negative impact on the Turkish Cypriot economy and may ultimately cripple it. 'Property' and the 'right to return' appear to be one of the, if not the most, intractable issues during the peace talks currently being held by Mehmet Ali Talat and Demetris Christofias, the leaders of the two communities. It can perhaps rival only the issue of military guarantees. Despite their earlier successes in

\footnotetext{
(Application no, 15318/89), main judgment delivered on 18 December 1996.

Turkey compensates Cyprus refugee, BBC News, 2 December 2003. Available on: http://news.bbc.co.uk/2/hi/europe/3257880.stm.

See, for example Demades v Turkey (Application no. 16219/90)

Eparchiako Dikastirio Lefkosias, Case No. 9968/04, 19 April 2005, Apostolidis v. D. and L. Orams.
} 
the 'battle of weapons,' the 'battle of books' is being lost by the Turkish side. Will this trend continue? Will any such continuation eventually undermine Turkey's resolve over Cyprus and make a compromise easier like the Greek side is hoping?

The aim of this article is to shed more light on the issues inherent in these questions. In this respect, regard will be given to the developments taking place at the ECHR and the ECJ in the last five years.

\section{Developments at the ECHR}

In the years following the famous Loizidou ruling, more than 1,000 applications were filed against Turkey in Strasbourg. In order to control this flood of litigation, the TRNC authorities passed Law No. 49/2003 and set up a property compensation commission. It was hoped that following this development, the ECHR would require the pending cases to be channeled to this body in the name of "exhausting local remedies" first. Still, the Court initially refused to give its blessings to this commission while finding the Xenides-Arestis v. Turkey application admissible. ${ }^{8}$ In the text of the relevant judgment, the following points could be highlighted: ${ }^{9}$

i) The rejection of the Annan Plan by the Greek Cypriot community has not altered the legal situation affecting property rights in land on the island;

ii) North Cyprus is still under the effective (military) control of Turkey and the latter continues to remain legally accountable for the human rights violations occurring therein;

iii) Most members of the commission are inhabiting property still legally owned by Greek Cypriots;

iv) The terms of compensation do not allow for the possibility of restitution for the property withheld. Although compensation is foreseen, this cannot be considered to be a complete system of redress regulating the basic aspect of the inferences complained of; and

v) The law that set up the commission has failed to address how it may provide effective remedies for potential violations of Article 8 and 14 of the European Convention of Human Rights that concern the rights to private life and freedom from discrimination.

Having said this, I would like to elaborate further on the last point and explain the international law norms that the Turkish Cypriot authorities have failed to comply with while addressing issues of the properties that had to be abandoned by Greek Cypriots in 1974-75.

8 (Application No. 46347/99), Decision on Admissibility delivered on 14 March 2005.

9 See pp. $18-45$. 
Expropriation criteria based on ethnicity is disallowed. Compensation may need to be accompanied by restitution

Even though an entity defining itself as a 'state' has not received international recognition, some of its domestic acts may be given legal effect. Traces of such an approach to international law could be found in a judgment delivered by Lord Wilberforce of the UK House of Lords. In Carl Zeiss Stiftung v. Rayner \& Keeler (No.2). ${ }^{10}$ He famously stated:

"In the United States some glimmerings can be found of the idea that non-recognition cannot be pressed to its ultimate logical limit, and that where private rights, or acts of everyday occurrence, or perfunctory acts of administration are concerned (the scope of these exceptions has never been precisely defined) the courts may, in the interests of justice and common sense, where no consideration of public policy to the contrary has to prevail, give recognition to actual facts or realities found to exist in the territory in question. '.

The International Court of Justice (ICJ) appeared to approve of this stance in its Advisory Opinion on Namibia. ${ }^{11}$

Article 159(1) (b) of the TRNC Constitution that came into force in 1985 lays down the provision that all properties that were deemed 'abandoned' on 13 February 1975 (the date when the Turkish Federated State of Cyprus - forerunner of the TRNC - was founded) belong to the State. Nearly all of the properties in Northern Cyprus that fell into this category on that date had Greek Cypriot title. Seen in that light, Article 159 (1) (b) can be considered to be aimed at expropriation based solely on ethnicity criterion. ${ }^{12}$

The relevant sections of the 1948 UN Universal Declaration of Human Rights, ${ }^{13}$ the 1966 Convention on Civil and Political Rights ${ }^{14}$, and the 1965 Convention on Racial Discrimination outlaw all forms of discrimination based on ethnicity and racial background. This view was reiterated by the ICJ in the Barcelona Traction Case. ${ }^{15}$ The US courts have expressed the view that this norm can now be considered jus cogens ${ }^{16}$ from which no derogation is permissible. Having said this, the foregoing provision of the TRNC Constitution appears to therefore violate international law and could not be considered valid under any circumstances. Yet, can this be taken to mean that all of the Greek Cypriot refugees should have a right to return? Is the ECHR effectively planting dynamite in the foundations of a bi-zonal solution to the Cyprus Dispute?

10 [1967] AC 853 at p. 954.

11 [1971] I.C.J.Rep. pp. 37-47.

12 James CRAWFORD, Legal issues arising from cerain population transfers and displacements on the territory of the Republic of Cyprus in the period since 20 July 1974, Opinion Issued to the 'Cypriot Government', June 1999.

3 Articles 1,2 and 7.

14 Articles 2 and 26.

15 [Belgium v Spain] ICJ Reports 1970, at p. 32.

16 Siderman de Blake v Republic of Argentina, 965 F2d. 699 (9th Cir.1992). 
How different is the treatment by the Greek Cypriot authorities of the properties in Southern Cyprus left behind by up to 65,000 Turkish Cypriots? An institution called The Guardian of Turkish Cypriot properties was set up by the Greek authorities, under Law 139/1991 as the caretaker of properties belonging to Turkish Cypriot refugees due to the extant circumstances i.e. the continuing division of the island. According to the law, the Guardian takes over the property until the Cyprus Dispute is resolved; then ownership is handed back to its legal owners in its original state. However, Turkish Cypriot refugees can reclaim possession and use of their real property in the south part of the island only if they have resided in areas controlled by the Greek Cypriot Administration for a continuous period of six months. ${ }^{17}$

This arrangement is a far better attempt to comply with international law. However, there are many instances where Turkish Cypriot land was utilized for public purposes without going through the formal acquisition procedure enshrined in Law 15/1962. So far, very few Turkish Cypriots have decided to take action on these irregularities. This can be attributable to: (i) a lack of state guidance for the aggrieved individuals; (ii) a lack of expertise amongst the Turkish lawyers on such technical matters; (iii) general mistrust of Greek Cypriot lawyers to vigorously defend Turkish Cypriot interests in South Cyprus courts or elsewhere; and (iv) mistrust of the courts of the South staffed by Greek Cypriots.

In the case of Cyprus, the right of return can be founded on: (i) UN resolutions concerning the island, (ii) international human rights law and (iii) past examples.

The 1907 Hague Convention obliged its signatories to endeavor to preserve the legal and social status quo in territories that may come under an occupying power's control following a military conflict. Throughout the two world wars, not many states purported to adhere to this rule. In recent history, property and population exchange following a war was first implemented in the 1919 Treaty of Neuilly signed between Bulgaria and Greece. As a result, 46,000 Greeks and 96,000 Bulgarians had to abandon their properties. A similar solution was adopted by the 1923 Lausanne Treaty, to which Turkey and Greece are signatories. In both cases, the governments confiscated the real properties of the original owners and used them for the settlement of arriving refugees.

By the end of the 1940s, this formula had become so popular that it was also adopted during the partition process of India and the re-location of Germans expelled from several countries in Eastern Europe. Of

17 Landmark decision of the Supreme Court of Cyprus, 12 December 2008, available at

http://www.klztlaw.com/news/landmark-decision-of-the-supreme-court-of-cyprus-11-09-2008. 


\section{Property Wars in Cyprus: The Turkish Position}

the 15 million Germans who had to leave their homes, 2 million perished in the process. In the second half of the $20^{\text {th }}$ century, a 'Neulliytype' solution for mass dislocations gradually fell into disfavor.

Annexes 4 and 7 of the 1995 Dayton Accords for Bosnia gave almost all refugees the right of return. ${ }^{18}$ UN Security Council Resolutions No. 361 and 365 (on Cyprus) 385 (on Namibia), 971 (on Abkhazia), 999 (on Tadjikistan) and 1009 (on Croatia) have been passed, based on this philosophy. UN General Assembly Resolutions No. 3212 (XXIX) and 3395 (XXX) also repeated the view that all Cypriot refugees should be allowed to return to their homes. On the other hand, several Security Council resolutions have given the green light to a solution to the $\mathrm{Cy}$ prus Conflict modeled on bi-zonality.

Despite the authorities just cited, the leading scholars are still divided on whether international law is clear on the precise scope of a potential right to return. Some professors like Eyal Benvenisti argue that international law is not yet ripe on this point. ${ }^{19}$ On the other hand, their views are contradicted by such academics as Eric Rosand. ${ }^{20}$ While hearing a case concerning Asians expelled by the Idi Amin regime in Uganda, the late Lord Denning went so far as to say that the issue of mass expulsions was not covered by international law. ${ }^{21}$ In a similar fashion, Jagersiold defended the view that dislocations on a large scale could only be addressed by a political solution. ${ }^{22}$ Rosalyn Higgins is of the view that a Bosnian-style solution is evolving into a norm of customary international law. Christian Tomuschat argues that such evolution has already taken place. ${ }^{23}$

This uncertainty will no doubt give the Turkish side some room to maneuver in any peace talks or in international courts. ${ }^{24}$ Making use of the lack of global consensus on the extent of right to return, the Turkish side had to work to ensure that the 'restitution' requirement would be interpreted in the least rigid manner possible by the ECHR. Above all, one must also give consideration to the position of bona fide investors or Turkish Cypriot refugees. Finally, the European Convention on Human Rights is expected to be given a constructive and dynamic interpretation as laid down under the 1969 Vienna Convention on the Law of Treaties.

18 Chapter One, Article I (1) of Annex 7, General Framework Agreement for Peace in Bosnia Herzegovina, 14 December 1995, 75 I.L.M. 138, reprinted in Office of the High Representative, Bosnia and Herzegovina, Essential Texts 16 (2nd ed.1998).

19 BENVENISTİ and ZAMIR, Private Claims for Property Rights in the future Israeli-Palestinian Settlement, 89 AJIL 295.

20 The Right to Return under International Law following Mass Dislocation: The Bosnia Precedent? 19 Michigan Journal of International Law 1091, at pp. 1130-31.

21 R v Secretary of State for the Home Department, ex parte Thakrar [1974] 1 QB 694

22 Freedom of Movement, in International Bill of Rights (Louis Henkin ed. 1981) 166, at p. 180.

23 Das Recht auf die Heimat: Neue rechtliche Aspekte, DES Menschen Recht Zwischen Freiheit und Verantwortung 183, at pp. 184-86 (Juergen Jekewitz et al. eds., 1989).

24 For a general brief on how customary international law norms evolve and become binding on states, note the following I.C.J. judgment: North Sea Continental Shelf: Federal Republic of Germany/Denmark; Federal Republic of Germany/ Netherlands, I.C.J. Reports 1969, at p. 3. 
Soon after the fall of the Berlin wall in 1989 and the German unification that followed thereafter, the issue of German properties in various Eastern European countries was once again raised in different forums. While Vaclav Havel, the last president of the then Czechoslovakia, admitted that the nature of German expulsion in the 1940s was both unethical and immoral, the so-called Benes Orders that triggered the fait-accompli confiscation of German properties were not withdrawn.

The 1990 Re-Unification Treaty referred to above stated that the expropriations undertaken by the Soviet occupation forces in East Germany between 1945-49 would be recognized while confirming that the primary remedy to be afforded to the aggrieved individuals would be compensation. It was stated that restitution would be refused on one of these grounds: (i) a return would be impossible or impractical or unjust; (ii) the land concerned is a source of major revenue for the society, or (iii) the property is in the hands of a bona fide purchaser who, at the time of purchase, was not aware of a possible violation of East German laws or administrative principles.

In order to accommodate international law and ease the pressure from Strasbourg, the Turkish Cypriot authorities, on 22 December 2005, enacted a revised "Law for the Compensation, Exchange and Restitution of Immovable (Real) Properties" (Law No. 67/2005). The authorities subsequently enacted a By-Law, which entered into force on 20 March 2006. A commission (the "Immovable Property Commission") was set up under Law No. 67/2005 to examine applications under that law and decide on whether restitution, exchange of properties or payment of compensation is appropriate. It is composed of five to seven members, two of whom are foreign members, Hans-Christian Krüger and Daniel Tarschys. There is also the remaining ability for subsequent appeal to the TRNC High Administrative Court and thereafter to the ECHR in Strasbourg.

In the last four years, the property regime in North Cyprus has been revised on different parameters and the right to a restitution of property has been limited on more objective grounds than ethnic background. The more recent law survived a challenge at the Supreme Court of the TRNC that upheld its validity. ${ }^{25}$ At the time of writing, the Grand Chamber of the ECHR was deliberating on the effectiveness of the new mechanism for applications on which admissibility decisions are yet to be reached. Since the TRNC is not a recognized member of the Council of Europe, the upgraded Immovable Property Commission will still be evaluated as an 'emanation of Turkey.'

Despite this, if the Court finally agrees with the Turkish proposi- 
tion that the Greek Cypriot applicants should first resort to the potential remedies available in North Cyprus this will be a huge sigh of relief for the Erdoğan government. This is because a verdict along these lines would delay the process of more than 1,400 Greek Cypriot claims for up to 5 or 7 years, giving Turkey more breathing space to reach a political solution to end court litigation for good. Regardless of the ruling the Grand Chamber is expected to deliver by early 2010, the ECHR will continue to hear around two dozen applications which it has already declared admissible. Failure to honor Strasbourg orders to pay compensation may create some unforeseen consequences for Turkey.

\section{Non-payment of judgments to Greek Cypriots may result in a Turkish Airlines plane being seized after landing at Charles de Gaulle Airport in Paris}

It may be a fair generalization to make that the Strasbourg judgments are binding upon the respondent states 'in honor only.' Normally, compliance with rulings is monitored only by the Committee of Ministers at the Council of Europe and the sanction of getting expelled from the Council has been considered to be an extreme outcome that has so far not materialized. However, a new formula which certain leading foreign lawyers are working on may make possible the execution of ECHR awards against commercial assets of the Turkish states situated in practically any other part of the world ${ }^{26}$.

The case of The Schooner Exchange v McFadden confirmed that the assets of a foreign state are immune against enforcement of a judgment or award rendered against the relevant state. ${ }^{27}$ There, the judgment creditor sought to seize a ship belonging to France after the debtor state defaulted in the re-payment of loans made to it. Yet, international law has moved on from this rigid principle since the 1920s. Now the immunity of states has been considerably undermined, especially where 'commercial investments' are in issue. In the U.S. and the UK, this adaptation is visible in the US Foreign Sovereign Immunities Act of 1976 and State Immunity Act 1978, respectively.

It is a well-established principle of corporate law that a company maintains a legal personality distinct from its shareholders. ${ }^{28}$ Accordingly, the Republic of Turkey and such internationally known enterprises as Turkish Airlines ought to be regarded as separate entities and the judgments rendered against Turkey should not have an impact on the assets of such corporations. Nevertheless, the so-called 'corporate veil' can be lifted in appropriate circumstances. Similarly, in early

\footnotetext{
26 Rumlardan Türkiye'ye haciz tehdidi, Milliyet Newspaper, 12 October 2009.

2711 U.S. 7 Cranch 116 (1812).

28 Salomon v A Salomon \& Co Ltd [1897] AC 22.
} 
1990s the ECJ held that state-owned companies like the British Gas could be evaluated as an 'emanation of the state.'

The inventors of the aforementioned formula want to frame ECHR decisions as an 'award' in the sense envisaged by the 1958 Convention on the Recognition and Enforcement of Foreign Arbitral Awards (the "New York Convention") so that they can be enforced in the state signatories to the New York Convention. It is the author's submission that ECHR judgments cannot be put into the same categories as arbitral awards. Hence, the idea in question has no applicability. Still, the field of law does not recognize many limitations to the imagination, or more truly, the interpretation of legal instruments.

\section{A new battlefront in Luxembourg}

In 1974, Meletis Apostolides, a Greek Cypriot architect, and his family were displaced from their property in Lapithos as a result of the Turkish intervention under the 1960 Treaty of Guarantee and subsequent population exchange arrangements.

In 2002, David Charles Orams and Linda Elizabeth Orams, from Hove, Sussex, England, invested $£ 160,000$ of their retirement fund to acquire the land from a third party (a Turkish Cypriot) and to construct a villa on the premises. The third party claimed to have acquired the property from the TRNC authorities in exchange for the land he left in the South. The Orams used the property in Cyprus for vacations and kept a separate property in the UK A year later, the authorities of Northern Cyprus eased crossing restrictions along the ceasefire line giving displaced Greek Cypriots the opportunity to visit their old properties. Mr. Apostolides visited his property and confirmed the construction of the house occupied by the Orams.

He thereafter promptly instituted proceedings in the Nicosia District Court in South Cyprus, demanding the immediate vacation of his property by the English couple. His case centered on the argument that although the government of Cyprus had lost effective control over the northern part of the island following the intervention, its laws still applied and he maintained title to the relevant land in west Kyrenia, i.e. Lapithos. This was even if the laws were not practically enforceable.

In November 2004 the Court claimed to have jurisdiction over land located in Kyrenia (North Cyprus) ordered the Orams to:

i) demolish the villa, swimming pool and fencing which they had erected on Mr Apostolides' land;

ii) deliver to him free possession of the land;

iii) pay the Plaintiff various sums by way of special damages and monthly rental charges (including interest) until the judgment was 


\section{Property Wars in Cyprus: The Turkish Position}

complied with;

iv) refrain from continuing with the unlawful intervention on the land, whether personally or through their agents, and

v) pay various sums in respect of the costs and expenses of the proceedings (with interest on those sums).

The Orams appealed this decision, which was heard at the Greek Cypriot Supreme Court. The appeal was dismissed.

Due to the island's division, the judgment reached by the Cypriot court was not enforceable in Cyprus and Mr. Apostolides resorted to the EU acquis communautaire to have it registered at the High Court of England and applied against the Orams' assets in the UK The procedure for the enforcement of judgments between Member States of the European Union is provided by Regulation No 44/2001. ${ }^{29}$ The combined effect of Articles 34, 35 and 36 of the Regulation is that enforcement of a judgment can be refused only if it can be shown that this would run counter to the 'public policy' of the Member State where recognition and enforcement is sought.

Since Cyprus is a member of the Commonwealth, UK Foreign Judgments (Enforcement) Act of 1933 could also have been relied on as the legal basis for such an attempt, but reliance was placed on an instrument that had EU-wide applicability.

The Orams were represented in the English courts by Cherie Blair, an action criticized by the then Greek Cypriot president Tassos Papadopoulos. He argued that due to its political nature, the wife of an acting prime minister (Tony Blair) should not be involved in such a case. In September 2006, the High Court of Justice ruled in favor of the English couple holding that since the application of acquis communautaire was suspended in North Cyprus, EU laws could not be relied on for an issue concerning land in the TRNC. ${ }^{30} \mathrm{Mr}$. Apostolides appealed the decision at the Court of Appeals which in turn referred the case to the ECJ in Luxembourg for a preliminary ruling under Article 234 of the EC Treaty.

The case was heard by the Grand Chamber as Case No. C*420/07. A panel of judges ruled on April 28, 2009 that British courts must enforce the judicial decisions of South Cyprus. ${ }^{31}$ This was even if a judgment concerned territories where EU laws had been suspended in conformity with Article 1(1), Protocol No. 10 of the 2003 Accession Treaty. At the time of writing, the English Court of Appeals is holding hearings to decide how to act following the ECJ ruling. The

29 Official Journal L 12 of 16.01.2001.

30 [2006] EWHC 2226 (QB), case no: B/2005/PTA/0897.

31 "Landmark court ruling means Britons could be forced to return homes in Northern Cyprus", The Daily Telegraph, 29 April 2009. 
matter, too, is likely to be settled in early 2010. The Turkish Cypriot leadership is hoping that the English court may exercise the residuary discretion mentioned in Article 34 of Reg. (E.C.) 44/2001 and refuse enforcement on public policy grounds. Nevertheless, such an outcome is unlikely because ECJ decisions are superior to those of domestic courts $^{32}$ and in this case it is a fact that the Grand Chamber has adopted a very rigid interpretation of the concept 'public policy,' rendering its chances of relevance to the facts of the Orams case being very slim.

\section{Implications}

The case has been described as a landmark test case as it sets a precedent for other Greek refugees to file similar actions in the courts. If upheld, the assets of people possessing Greek Cypriot properties in the North could be targeted anywhere in the EU in this manner. The importance of the case is illustrated by the fact that the Orams defense was funded by Turkish property developers and the Turkish government while Mr. Apostolides was supported by Greek-Cypriot interests ${ }^{33}$.

Both the British High Commission in Cyprus and the Foreign and Commonwealth Office have issued warnings regarding the purchase of property in Northern Cyprus. ${ }^{34}$ Around $70 \%$ of the land in the North had title held by Greek Cypriots before $1974 .{ }^{35}$ The Orams ruling may have the effect of terrorizing foreign investors and Turkish Cypriots alike investing in property where there may be a claim of Greek Cypriot ownership. The problem may become even more acute if the Greek Cypriot administration's threats come to fruition about issuing 'European Arrest Warrants' against those foreigners and Cypriots engaging in what they call unauthorized dealings with land in the North that is subject to those claims. ${ }^{36}$

\section{Final remarks}

In the last 35 years that has passed since the intervention, reaching a peaceful and comprehensive settlement to the "Cyprus Dispute" has proven to be impossible. Presently, there is a 'cease-fire' within the territory of Republic of Cyprus that continues to maintain a legal personality and recognition in international relations. International law summarizes the position of the island using these terms.

During the time that has passed, the Turkish side has achieved certain diplomatic victories on the international plane. In 1975, the population exchange agreement referred to above was signed. Between

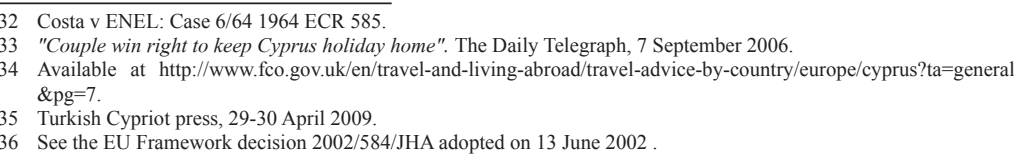




\section{Property Wars in Cyprus: The Turkish Position}

1977 and 1979, this was followed with two 'High Level Agreements' that envisaged a bi-zonal and federal solution to the Cyprus Dispute. Each of these three documents were painful concessions made by Glafkos Clerides, Archibishop Makarios III and Spiros Kyprianou that rocked the domestic politics of South Cyprus.

Nevertheless, none of these instruments would be sufficient to overturn several UN resolutions and European judgments. In essence, this is because of the fact that they do not have the status of a 'treaty' signed between states and deposited with the UN Secretariat in conformity with Article 102 of the UN Charter. They can at most be considered 'memoranda of understanding' signed between two communal leaders which do not have conclusive binding effect. Seen through this angle, their status is analogous to phrases written on ice. The wording of certain UN Security Council resolutions 'favoring' the idea of a bi-zonal settlement in the island cannot be used to render impotent certain individual rights concerning return. The relevant resolutions are not crowned by a political solution having legal implications.

On the other hand, a long-term continuation of the status quo may result in snowballing Arestis, Loizidou and Orams-type litigation. This can have the effect of further diluting or neutralizing the limited diplomatic gains made by the Turkish side in recent decades. A permanent settlement founded on the principle of bi-zonality and 'severely limiting' the right of return would retrospectively ratify, to a great extent, certain administrative irregularities concerning the Greek Cypriot-claimed land in North Cyprus. Such an arrangement would be in harmony with Articles 25 and 103 of the UN Charter and not run counter to the jus cogens norms of international law. ${ }^{37}$ Thus, no issues under Article 53 of the Vienna Convention on the Law of Treaties, 1969 would likely arise.

The successful conclusion of Cyprus' accession talks that led to full EU membership on 1 May 2004 has had a negative impact on the balance of power in the region as the Greek side can now legitimately count on the political support of a 27-member EU in the further stages of peace talks. The progress of Turkey's own accession talks will inevitably trigger a gradual de facto Turkish recognition of a government dominated exclusively by Greeks as the sole representative of Cyprus as a whole. This is a concern shared by most Turkish Cypriots. However, major European powers, like France and Germany, that are sceptical of the idea of a full Turkish integration into the Union may increasingly rely on the Cyprus issue to slow down the process.

Future developments are likely to be intertwined with many un-

37 Quigley, Mass Displacement and the Individual Right of Return, British Yearbook of International Law, Vol.68 [1997], at p. 65 . 
predictable political calculations. The degree of intra-European integration and the strategic importance of Turkey in reducing European dependence on Russian energy resources in an era of a resurgent and increasingly authoritarian Putin-Medvedev regime will influence the way developments will be shaped. There are still too many unknowns at this stage. What the future will bring remains to be seen! 